Edgar Pereira

https://orcid.org/0000-0001-8547-6777

University of Coimbra

\title{
AN INSTRUMENTAL CONNECTION. ECONOMIC DIPLOMACY, INTERNATIONAL ARMS TRADE AND OVERSEAS ASPIRATIONS BETWEEN PORTUGAL AND SWEDEN, 1640-80
}

\begin{abstract}
This paper offers an Iberian perspective on Sweden's 'Age of Greatness' by looking at the intersection of international politics and trade involving Portugal and Sweden after Portugal regained its independence from Spain at the end of 1640. Sweden's exports of timber, naval stores, iron, copper, and weapons to Braganza Portugal are seen in the context of the Portuguese wars for overseas trade and colonial settlement against the Dutch Republic and the struggle for autonomy against Spain in its home turf. By revisiting the accounts of diplomatic actors, this contribution will discuss how Portugal turned to Sweden for diplomatic recognition and new consumption markets and carriers for its export sector. It will also be shown how Sweden stood to gain by adding a new customer to its military export sector and by tapping into Portugal's colonial goods and salt, while at the same time it entertained the prospect of using the Portuguese offshoots in West Africa and the East Indies to further its ambitions in overseas trade.
\end{abstract}

Keywords: new diplomatic history, Luso-Swedish relations, actor-based approach, economic diplomacy, arms trade, early-modern overseas expansion, salt trade

\section{INTRODUCTION}

For almost two decades now, the diplomatic history of the pre-modern period, which was once considered one of the most conservative and 
unexciting of historical sub-disciplines, has undergone comprehensive renewal. $^{1}$

Among the novelties introduced by this historiographical turn is an inventive actor-based approach that has dramatically expanded our notion of what constitutes a diplomatic actor before the advent of the 'nation-state'. Not content with acknowledging the input of individuals who were not accredited ambassadors, extraordinary envoys or consuls, present-day historians also have a better grasp of the complex and, at times, contradictory motivations behind their actions. They exposed the anachronism of viewing early-modern diplomatic actors as devoid of their own individual or group motivations and purely driven by their loyalty and zeal to their sovereign. ${ }^{2}$ Thanks to these inquiries, there is a growing awareness that the individuals who represented central polities abroad spent as much time trying to implement the international agendas of rulers as they pursued their personal strategies and advocated on behalf of particular interest groups. These interest groups could include court-nobility factions, merchant elites based in their home country or abroad, officials with a university background in law, and prominent clergymen. ${ }^{3}$

Inspired by these historiographic revisions, this article reassesses how international politics and long-distance trade, in Europe and overseas, bound together seventeenth-century Sweden and Portugal. This topic has been studied in the past, but never through the lenses of new diplomatic history, as it is here. This article attempts to answer two fundamental questions: First, what could gain the Portuguese Crown and political-economic interests with ties to the court by establishing stable and fruitful relations

1 John Watkins, 'Toward a New Diplomatic History of Medieval and Early Modern Europe', Journal of Medieval and Early Modern Studies, 38, no. 1 (1 Jan. 2008), 1-14; Tracey A. Sowerby and Jan Hennings, 'Introduction', in Practices of Diplomacy in the Early Modern World c. 1410-1800, ed. by Tracey A. Sowerby and Jan Hennings (New York: Routledge, 2017), pp. 1-21.

2 Birgit Tremml-Werner and Dorothée Goetze, 'A Multitude of Actors in Early Modern Diplomacy', Journal of Early Modern History, 23, no. 5 (2019), 407-22; Tracey A. Sowerby, 'Early Modern Diplomatic History', History Compass, 14, no. 9 (2016), 441-56.

3 Cátia Antunes, 'Dutch-Portuguese Diplomatic Encounters, 1640-1703: Exchanges, Sovereignty and "World Peace"', Journal of Early Modern History, 23, no. 5 (2019), 458-74. 
with Sweden. Second, what can a Portuguese vantage point tell us about Swedish commercial ambitions and early overseas ventures?

It is argued in this contribution that, while the Nordic monarchies did not rank among Portugal's closest diplomatic partners, Portuguese strategic interests with regard to Scandinavia and the Baltic nonetheless grew after 1640. In turn, by surveying Sweden's relations with a newly independent state located at the terminus of Western Europe, it will become clear how this Scandinavian empire was also broadening its geopolitical horizons in the second half of the century.

This article also contends that commercial and political aspirations were best articulated by diplomatic actors of different backgrounds, who relied on networks of contacts, at home and abroad, and on their perceptive reading of the internal and international contexts to exploit any opportunities that might arise.

The article addresses three of the five constituting elements of imperial diplomacy highlighted in the introduction to this issue. They are, first, 'Learning', as the article examines how the Swedish Crown and merchants hoped to draw from Portugal's centuries' long colonial experience to establish their own Atlantic empire. Second, 'Negotiation' by considering how the Portuguese Crown sought to persuade Sweden's envoys to Münster and Osnabrück to allow Lusitanian representatives, who were denied official diplomatic recognition at the summit, to join them and voice some of their concerns. Lastly, 'Connections', in so far as the article addresses how Portuguese and Swedish interests looked to each other to secure new markets for their exports and obtain in-demand import goods for their respective economies (and, in Portugal's case, also for its armies).

Structure wise, the article begins by explaining the internal and external context that made the Portuguese authorities look at Sweden as a political ally and commercial partner, after which the structural features of the trade between Portugal and the 'Scando-Baltic region' will be outlined. ${ }^{4}$ These features provided the foundation upon which diplomatic

${ }^{4}$ I borrow here from Lilja's concept, which refers to the historical-geographic complex spanning the Scandinavian Peninsula, Finland, Baltic Russia, Poland, and Prussia. Sven Lilja, 'Peoples, Towns and States. Structural Power Resources and State Power in the Scando-Baltic Region (1500-1820)', in The Dynamics of Economic Culture 
relations between the two monarchies were built. Subsequently, the agreements and treaties that furthered the political and economic relations between the two states are revisited. The article examines the instructions given to the external affairs envoys dispatched by Lisbon and Stockholm and the practical results they achieved during their commissions. Taken together, the instructions given to and the actions of the diplomatic actors to them reflect the ambitions, not only of the royal and ruling elites in both monarchies but also of interest groups in the sale of arms and in colonial and bulk trades. ${ }^{5}$

\section{ACKNOWLEDGEMENT, SUPPORT AND COOPERATION: THE DIPLOMATIC GOALS OF BRAGANZA PORTUGAL IN AN ADVERSE INTERNATIONAL CONTEXT}

The period that spanned Portugal's acrimonious split from the Hispanic monarchy in December 1640, and the peace settlement of 1668, was one of the most convoluted in the country's history.

For twenty-eight years, war was fought on the home turf, something Portugal had not experienced since the fifteenth century, and on its South Atlantic and the Indian Ocean possessions. ${ }^{6}$ These overseas conflicts did not pit Portugal against Spain but rather against the Dutch Republic and should, therefore, be seen as a continuation of the rivalry that went back decades to when the Portuguese empire was part of the domains of the House of Habsburg. For a small kingdom with a vast but thinly spread empire, like Portugal, sustaining a war effort on an unprecedented scale and four different continents depended on obtaining diplomatic support from more powerful states and accessing the international arms trade circuits.

in the North Sea and Baltic Region in Late Middle Ages and Early Modern Period, ed. by Hanno Brand and Leos Müller (Hilversum: Verloren, 2007), pp. 24-46.

5 A similar conclusion is drawn by Hannula and Wirta in this special issue. They conclude that the objectives of certain economic interest groups did not necessarily take a back seat to the high political goals of their sovereigns and not infrequently ended up having primacy in the early modern diplomatic negotiations.

${ }^{6}$ Jorge Borges de Macedo, História diplomática portuguesa: constantes e linhas de força, vols 1-2, 2nd edn (Lisbon: Tribuna da História, 2006). 
When it became clear that the coup d'état led by the Duke of Braganza was successful and that the kingdom was firmly behind its new sovereign, the priority for the new Portuguese authorities became anticipating Spain's military and diplomatic counter-attack and consolidating the country's newly regained autonomy. ${ }^{7}$ A diplomatic campaign without parallel in the country's history up to that point was launched to achieve that goal.

Naturally, the aspirations of the new Braganza king and its base of support were vehemently opposed by Spain, which brought the full weight of its armies and its diplomatic influence to bear on the breakaway kingdom. To vanquish what it perceived as an internal uprising, the Spanish Monarchy attempted to isolate its former territory in the international scene. The Habsburgs' allies instantly became Portugal's enemies and did not recognise the rule of the Braganza. Regarding those other states that were not necessarily hostile towards the new Portuguese regime, Spain's approach was to secure their neutrality and ensure they did not intercede on the country's behalf. In the eyes of Phillip IV, the Portuguese were seditious rebels, and the military campaigns on Castile's western border were a matter of domestic politics in which foreign powers should not meddle. From Madrid's point of view, depriving the Portuguese rebels of outside support and isolating them in the international arena was only a matter of time before they were beaten into submission. ${ }^{8}$

Fortunately for the Braganza rule, Spain's aggressive diplomatic manoeuvres were not immediately replicated on the battlefield. Neither landed troops, nor naval contingents attacked Portugal right away because the Hispanic monarchy had more pressing military concerns elsewhere. ${ }^{9}$ Also, in 1640, a revolt broke out in Catalonia (which Madrid

7 Leonor Freire Costa and Mafalda Soares da Cunha, D. João IV (Rio de Mouro: Círculo de Leitores, 2006).

${ }^{8}$ Rafael Valladares, La rebelión de Portugal: guerra, conflicto y poderes en la monarquía hispánica, 1640-1680 (Valladolid: Junta de Castilla y León-Consejería de Educación y Cultura, 1998).

${ }^{9}$ On the naval constraints that prevented Spain from launching an attack against the Portuguese coast and take control of its ports; Rafael Valladares, 'La Dimensión Marítima de La Empresa de Portugal (1640-1668)', in 'Por Toda La Tierra'. España 
prioritised over Portugal). At the same time, in Central Europe and Flanders, the Spanish armies continued to fight the dynastic, religious and geopolitically-motivated wars of the House of Habsburg. Fears of another long war of attrition, reminiscent of the Eighty Years' War against the break-away territories that formed the Dutch Republic, explain Spain's cautious and delayed military reaction to the secessionist coup in Portugal. On the other hand, Madrid knew that without backing a foreign power, the likelihood of an offensive launched from Portugal was small, so it bid its time, waiting for the moment it could spare troops to the western border. Madrid's reasoning was not of wide the mark. In years that immediately followed the coup d'état, the actions of the Portuguese army did not go beyond a few raids across the border and the occasional skirmish. Much to the chagrin of the enemies of the Hispanic monarchy, no sustained, vigorous offensive into the Spanish heartland was attempted. This lack of initiative was particularly off-putting for the French monarchy, which was Portugal's most obvious allies on account of being Spain's sworn enemy. Cardinal Richelieu hoped that Phillip IV would spread its armies even more thinly with the opening of a new war front and would be forced to move troops away from the war theatres where it clashed with the Bourbon armies.

The Portuguese Crown's ambitions of establishing an anti-Habsburg coalition did not come to fruition mainly due to France and Sweden's unwillingness to commit to it without the Dutch Republic also being on board. The worsening of the Portuguese-Dutch relations during the 1640s-50s and the Dutch-Spanish rapprochement after the end of the Eighty Years' War meant that one of the instrumental goals of the Portuguese foreign policy could not be attained. ${ }^{10}$ Instead, Portugal's ambassadors, residents, consuls and extraordinary envoys made it their utmost priority to prevent the signature of peace treaties between the

y Portugal: Globalización y Ruptura (1580-1700) (Lisbon: Cham, 2016), pp. 340-52. For the mobilisation of Spanish land forces in the years and decades after the 1 December 1640 coup; Lorraine White, 'Strategic Geography and the Spanish Habsburg Monarchy's Failure to Recover Portugal, 1640-1668', Journal of Military History, 71, no. 2 (2007), 373-409.

${ }^{10}$ Manuel Herrero Sánchez, El Acercamiento Hispano-Neerlandés (1648-1678) (Madrid: Consejo Superior de Investigaciones Científicas, 2000). 
Hispanic monarchy and its enemies that had not acknowledged Portugal's newly regained independence. Allowing such treaties to be ratified was tantamount to leaving Portugal on its own to face the might of the Hispanic monarchy, a contest of wills that the House of Braganza could not possibly win.

Notwithstanding its inability to assemble a defensive and offensive bloc against the common enemy, Braganza Portugal still stood to gain by signing bilateral treaties with individual states. The most crucial advantage to be gained was financial, material and logistic assistance in the upcoming wars. As a result of such agreements, the foreign military came to fight alongside the Portuguese troops. Some assembled their own regiments in their domiciliary states, and others were hired to command and train Portuguese battalions. ${ }^{11}$ Shipments of arms and ammunitions were dispatched to Lisbon and other ports of the kingdom, and heavily armed vessels from Portugal's new-found continental allies, France and the Netherlands, patrolled the coastline.

\section{SALT, ARMS AND INTERNATIONAL AID. THE EARLY PROMISE OF THE SWEDISH-PORTUGUESE ALIGNMENT OF INTERESTS}

Immediately following the 1640 coup d'état and the enthronement of João, Duke of Braganza (who became King João IV), envoys were dispatched to plead the case of the new ruling dynasty before several European courts and garner the support of Spain's rivals. Diplomatic missions were sent to France, the Dutch Republic and Sweden, the three champions of the anti-Habsburg cause, and Denmark, who was much more sympathetic to Spanish interests. ${ }^{12}$

11 Jorge Penim de Freitas, $O$ combatente durante a guerra da restauração: vivência e comportamento dos militares ao serviço da coroa portuguesa 1640-1668 (Lisbon: Prefacio, 2007); John Childs, 'The English Brigade in Portugal, 1662-68', Journal of the Society for Army Historical Research, 53, no. 215 (1975), 135-47.

12 On the establishment of cordial diplomatic and commercial relations between Spain and Denmark following a series of disastrous Danish campaigns in the Thirty Years War at the turn of the 1620s. Edgar Pereira and Kaarle Wirta, 'A Forgotten Emporium: Commercial Aspirations and Transnational Mercantile Networks in Seventeenth-Century Glückstadt', in Locating the Global. Spaces, Networks and Interactions from the Seventeenth to the Twentieth Century, ed. by Holger Weiss (Berlin-Boston: 
The envoys sent by the Portuguese Crown to Sweden were given five goals. (1) The official recognition of Portugal as an independent kingdom and the acknowledgement of its new ruling house; (2) Ensure that Portuguese envoys were given a seat at the negotiations table at the peace summit of Münster and Osnabrück; (3) the constitution of a united-front between Braganza Portugal, France, the Dutch Republic and Sweden against the House of Habsburg, that is against Spain and the Holy Roman Empire; (4) the personal commitment of the Swedish monarch, Queen Christina, to the freeing of prince Duarte, the brother of the new Portuguese king who was imprisoned by the Habsburgs in Milan in retaliation for the Braganza coup; (5) material support to Portugal's war effort against Spain.

For Sweden, the end of the Union of the Iberian Crowns was of little political consequence, but, as Edgar Prestage and Karl Mellander have noted long ago, there was much to gain from an economic standpoint. Upon hearing the news of the Portuguese uprising, the agent of the Swedish Crown in Hamburg, John Adler Salvius, reached out to the emporium's Portuguese Nation and inquired about the motherland's sympathies towards Sweden and whether the country would be looking for arms, ammunition, naval and metal wares that Stockholm could arrange. Apparently, the Vasa agent stationed in the Lower Elbe port was optimistic about the business opportunities that the dynastic change could create. ${ }^{13}$ This same feeling was allegedly echoed by the leading Swedish statesman of the time, Axel Oxenstierna. When asked about the gains of establishing stable diplomatic relations with Braganza Portugal, he was quoted as saying: 'We can get a barrel of salt for 8 dalers for which we formerly paid $14^{\prime} .{ }^{14}$

De Gruyter, 2020), pp. 17-40; Jonathan I. Israel, 'The Politics of International Trade Rivalry during the Thirty Years War: Gabriel de Roy and Olivares' Mercantilistic Projects, 1621-1645', in Empires and Entrepots: Dutch, the Spanish Monarchy and the Jews, 1585-1713 (London-Ronceverte: The Hambledon Press, 1990), pp. 237-39.

13 Durval Pires de Lima, 'As Relaçóes de Portugal Com a Suécia Durante a Restauraçáo', Separata de Anais Da Academia Portuguesa de História, 7 (Publicaçóes comemorativas do duplo centenário da Fundação e Restauração de Portugal) (1942), p. 349.

${ }^{14}$ Karl Mellander and Edgar Prestage, The Diplomatic and Commercial Relations of Sweden and Portugal from 1641 to 1670 (Watford: Voss and Michael, 1930), pp. 47-48. 
To see how Portugal's departure from the Spanish Monarchy could benefit Sweden's economy, we need to address the structural features of the trade between Iberian and Scandinavia. In the late Middle Ages, carriages were in the hands of third parties, first the Hanseatic League, and then, from the sixteenth century onwards, belonged to merchants and skippers operating in the Amsterdam staple market. As a result, there was little direct contact between Portuguese and Nordic ports for centuries since ships hosting a Portuguese or a Swedish flag did not normally connect the two kingdoms. Instead, their ports were part of more intricate commodity chains spanning production outlets, consumption markets and transhipment points from the Baltic to the Mediterranean and the Levant. ${ }^{15}$

In these exchanges, the role played by Portuguese salt cannot be stressed enough. It is not an overstatement to claim that it lay at the centre of the seafaring life in the Northern Sea and the Baltic. Salt eclipsed other Portuguese exports, such as picked fruits, wine and olive oil produced in the kingdom and even the luxury goods of colonial origin, such as sugar from Brazil. Lisbon's exports of pepper and Asian spices, along with precious stones, luxurious cloths and a variety of other non-bulk products, ceased to be in demand in the Swedish markets at the start of the seventeenth century, under the cut-throat competition of the English and especially Dutch charted companies, the English East India Company (EIC) and the Dutch East India Company (VOC).

In turn, Portugal, which lacked a booming manufacturing sector and was periodically dependent on imports of grain to feed the population of its towns, was a steady consumer of Nordic timber, iron and copper, including smelted artillery, as well anchors and nails, rigging, hemp, pitch and tar, and most important of all, Baltic wheat and rye. Therefore, the exploitation and defence of the far-flung Portuguese

15 Ana Sofia Ribeiro et al., 'Portugal and the Baltic Trade. An Overview, 1634-1800', in Seaports in the First Global Age. Portuguese Agents, Networks and Interactions (1500-1800), ed. by Amélia Polónia and Cátia Antunes (Oporto: U. Porto Ediçôes, 2016), pp. 115-62; Magnus Mörner, 'Swedish Trade and Shipping with the Iberian Peninsula. From the 16th Century to the 19th Century', in III Spain and Sweden: Encounters Throughout History, ed. by Enrique Martínez Ruiz and Magdalena Pi Corrales (Puertollano: Berndt Wistedt, 2000). 
empire depended on raw materials and manufacturing capability that could not be found in the motherland. The kingdom relied on foreign carriers to obtain these products. Both Crown and traders found it financially convenient to freight ships in Holland or the Hanseatic towns to bring over imports and equally place their exports in the foreign consumption markets.

Formal diplomatic relations between the Swedish and Portuguese Crowns were opened by the embassy of Francisco Sousa Coutinho, and his secretary, the jurisconsult Dr Moniz de Carvalho, to Stockholm. Son of a merchant-nobleman with ties to the transatlantic slave trade and the top-brass of the colonial administration of Portuguese Atlantic Africa, ${ }^{16}$ Sousa Coutinho was one of the few cadres of the Braganza administration with extensive diplomatic experience. ${ }^{17} \mathrm{He}$ had become a seasoned diplomatic delegate when he served as a representative of João IV, then Duke of Braganza, at the Spanish court before 1640. Having left Lisbon for Scandinavia in February 1641, Sousa Coutinho reached Sweden in May, following a stopover in Denmark, where he was granted a brief, not official audience with the Spanish-sympathising Christian IV.

Sweden's governing elite relished the prospect of ratifying a trading agreement that granted Swedish ships access to Portuguese ports and trade tariffs identical to those paid by other friendly nations. Conversely, there was more caution regarding a full-blown political-military alliance between the two realms, particularly the plans for the anti-Habsburg league pitched by the Portuguese envoys. Instead, the Vasa authorities tried

16 Gonçalo Vaz Coutinho had been tax-farmer of Angola and was the brother of the governor of that African colony at the start of the century. Miguel Geraldes Rodrigues, 'Between West Africa and America. The Angolan Slave Trade in the Portuguese and Spanish Atlantic Empires (1560-1641)', PhD dissertation (Firenze: European University Institute, Department of History and Civilization, 2019).

${ }_{17}$ For an sociological outline of the Portuguese diplomatic corps during the period under consideration; Pedro Cardim, Nuno Gonçalo Monteiro, and David Felismino, 'A Diplomacia Portuguesa No Antigo Regime. Perfil Sociologico e Trajectórias', in Optima Pars. Elites Ibero-Americanas Do Antigo Regime, ed. by Nuno Gonçalo Monteiro, Pedro Cardim, and Mafalda Soares da Cunha (Lisbon: Imprensa de Ciências Sociais, 2005), pp. 277-337. 
to make a case for how much Portugal had to gain from Sweden's naval stores' exports, its metallurgical sector and canon-smelting industry. ${ }^{18}$

The two sides were very much in agreement that the trade should run unimpeded by embargoes of any sort and that Swedish merchant ships should ensure the flow of merchandise between the two kingdoms. The goal of having the Swedish merchant marine competing with the Dutch carriers and breaking their quasi-monopoly on freightage was, therefore, already in the mind of both governments. All ships charted in Swedish ports were encouraged to come to Portugal with timber, tar, pitch and military wares, as well as iron and copper. On the return trip, they could bring luxury goods from Portugal's overseas offshoots, as well as fruits, wine, olive oil, and, it goes without saying, salt.

With this initial agreement, Sousa Coutinho ensured that the Portuguese Crown could get its hands on the naval stores and metal wares it needed to outfit its transoceanic ships and reinforce the country's lines of defence against Spanish aggression. It equally opened a new market for Portugal's exports of sugar, other cash crops and luxury products, which were suffering at the hands of the English and especially Dutch competition. The same applied to salt, which the Portuguese marketed as the very best in Western Europe, ahead of the production from Spanish and French salt-pans, and was in high demand in the domains of the Swedish Monarchy. ${ }^{19}$

The commercial clauses of the pact of alliance and mutual assistance, ratified on 29 July 1641 by Sousa Coutinho and the Swedish authorities, stipulated that grain, fire-arms and ammunitions would not pay tariffs at Portuguese ports, while naval stores and metal wares would pay the same duties levied on other friendly nations. ${ }^{20}$ In exchange for

18 Evaldo Cabral de Mello, O Negócio Do Brasil. Portugal, Os Países Baixos e o Nordeste (1641-1669) (Lisbon: Comissão Nacional para as Comemoraçóes dos Descobrimentos Portugueses, 2001), pp. 109-10.

19 Mellander and Prestage, Diplomatic and Commercial Relations, pp. 23-56.

20 As part of this agreement, the Swedish Crown also pledged to assist Portugal in freeing Prince Duarte of Braganza. It was also agreed that the project of an anti-Habsburg coalition would be discussed at later date, and that Sweden would intercede to have Portugal included in the peace negotiations of the Thirty Years' War. The twenty nine clauses of the pact alliance and support are transcribed in full in José Ferreira Borges de Castro, Colleccao dos Tratados, Convencoes, Contratos e Actos 
their exports, subjects of the Swedish Crown were allowed to acquire perfumes, wine and especially salt, which immediately became a veritable hard currency to settle trade imbalances between the two monarchies. Further, commercial privileges similar to those granted to merchants of other friendly nations, such as the Hanseatic, Flemish, Dutch and English, were extended to Swedes visiting or residing in Portugal. It was agreed that the local authorities would not trouble them but would respect the visiting and residing Swedes' property rights and refrain from requisitioning their ships for war and other emergencies.

Freedom of consciousness was extended to Swedish subjects during their stay in the country. The Portuguese authorities guaranteed they would not be harassed by the inquisition, as they did for English and Dutch merchants. As long as Swedish visitors and diplomatic envoys practised their protestant faith away from the public gaze, in the privacy of their houses and lodgings or onboard a ship at enough distance from the coast, they would have nothing to fear. As long, of course, as Swedish naturals were not caught trying to convert Catholics to their faith. ${ }^{21}$

Another concern for the Vasa and later the Wittelsbach authorities was the jurisdiction over their subjects on Portuguese territory. The Swedish Crown sought to appoint a permanent representative in the Lusitanian ports, a resident who was granted judicial competence to adjudicate disputes involving his country-mates and seek compensation if the local authorities threatened their well-being and property rights. Sousa Coutinho promptly accepted this request.

The repercussions of this appointment for the history of Swedish foreign affairs were far-reaching, for the inception of a Swedish resident in Lisbon primarily devoted to matters of trade and shipping paved the way for the future appointment, some twenty years later, of Sweden's first acting consul in a foreign port-city. As Leos Müller reminded us some years ago, Sweden's oldest consulate was set up precisely in Lisbon. ${ }^{22}$

Publicos Celebrados Entre a Coroa de Portugal e as Mais Potencias, vol. 1 (Lisbon: Imprensa Nacional, 1856), pp. 50-81.

${ }^{21}$ Lima, 'As Relações de Portugal'.

${ }^{22}$ Leos Müller, 'Swedish Trade and Swedish Consular Services, 1700-1800', in A Articulação Do Sal Português Aos Circuitos Mundiais. Antigos e Novos Consumos / The Articulation of Portuguese Salt with Worldwide Routes. Past and New Consuption Trends, 
With the two governments seeing eye to eye on trade and arms purchases, convoys were dispatched by the Swedish Crown to Lisbon, where they deployed military equipment so desperately needed by the Portuguese armies. To illustrate the composition of the military cargoes dispatched with the assistance of the Swedish state, we will consider the fleet of three ships that sailed off Gothenburg on 30 September 1641. It carried 40 bronze cannons, 1000 cuirasses, 1000 pistols, 4000 muskets, a great (but unspecified) amount of pikes, gunpowder, steel and 30 large masts. It dropped anchor at the Tagus in the last days of November and returned to Sweden in February of the following year. ${ }^{23}$

In the years that followed, navigation and trade between that Scandinavian monarchy and the newly independent Iberian kingdom picked up steam. Unlike the 1626-1641 period, for which the Sound Toll registers show the trade between Lisbon and Swedish ports coming to a standstill, following the diplomatic agreement brokered by Sousa Coutinho, nine ships sailed on average between Portugal and Sweden every year. ${ }^{24}$

The overall majority of these ships were part of the convoys launched by the Swedish Crown or by the trade companies it chartered. Nevertheless, a good deal of the shipping linking the two regions remained in the hands of Dutch carriers, and multilateral connections linking several ports, more than bilateral trade, were the norm. Voyages launched in Holland or Zeeland or arranged by freighters operating in these outlets ensured that cargoes circulated between Portuguese and Scandinavian-Baltic ports. This was, more often than not, a transhipment trade.

ed. by Inês Amorin (Oporto: IHM-UP, 2008), pp. 161-82; Leos Müller, Consuls, Corsairs, and Commerce: The Swedish Consular Service and Long-Distance Shipping, 1720-1815 (Uppsala: Coronet Books Incorporated, 2004).

23 'Relação das armas que do Reyno de Suecia tras Francisco de Sousa Coutinho, embaixador as partes Septentrionais, em três naos de guerra' (1642), published in Moses Bensabat Amzalak, A embaixada enviada pelo Rei D. João I Và Dinamarca eà Suécia: notas e documentos (Lisboa: Gráfica do Instituto Superior do Comércio de Lisboa, 1930), p. 31.

${ }^{24}$ Mainly as a result of the anti-Dutch embargoes imposed by the Habsburg authorities after the Twelve Years' Truce (1609-1621), even if myriad expedients were used to bypass them. Ribeiro et al., 'Portugal and the Baltic Trade. An Overview, 1634-1800'; Virgínia Rau, 'Subsídios Para o Estudo Do Movimento Dos Portos de Faro e Lisboa Durante o Século XVII', Separata de Anais Da Academia Portuguesa de História, 2a , no. 5 (1954), 199-277. 
While trade between the two monarchies picked up steam after the ratification of the 1641 diplomatic agreement, some thought that its full economic potential was not seized. This was the opinion of the first Swedish resident in Portugal, Lars Skytte. Skytte was a controversial figure who, for unclear reasons, converted to Catholicism and became a Franciscan friar, a religious conversation that caused much commotion back in Sweden. ${ }^{25}$ Before embracing the religious life, Skytte blamed the failure to bring the Portuguese-Swedish trade to greater heights to his country mates. According to him, local merchants in Lisbon, Setúbal and other towns were eager and ready to do business with Swedish traders and skippers and cut off the Dutch middlemen. However, Swedish merchants struggled to get acquainted with the ways of doing business in Portugal and showed little interest in learning the language. In that regard, they were no match for their German, Flemish and Dutch counterparts established in the kingdom for many decades, and were, thus, well accustomed to the local ways of doing business and well-known in Portugal's trade circles. ${ }^{26}$

\section{THE LATE 1640S AND THE 1650S. PORTUGAL'S MILITARY AND COLONIAL PREDICAMENT AND SWEDEN'S OVERSEAS ASPIRATIONS}

As the negotiations in Münster and Osnabrück drew to a close, and there was finally an end in sight to the Thirty and Eighty Years' Wars, the Portuguese position got more complicated. ${ }^{27}$ At the request of

${ }^{25}$ Lima, 'As Relações de Portugal', pp. 362-64.

26 Jorun Poettering, Migrating Merchants: Trade, Nation, and Religion in Seventeenth-Century Hamburg and Portugal (Berlin-Boston: de Gruyter, 2018); Cátia Antunes, 'Failing Institutions: The Dutch in Portugal and the Tale of a Sixteenth-Century Firm', Storia Economica, 18, no. 2: Reti Finanziarie e Reti Commerciali. Operatori Economici Stranieri in Portogallo (XVI-XVII Secolo), ed. by Benedetta Crivelli and Gaetano Sabatini (2015), 331-47; Eddy Stols, 'A “naçáo” Flamenga Em Lisboa', in Flandres e Portugal. Na Confluência de Duas Culturas, ed. by John Everaert and Eddy Stols (Antwerp: Ediçôes Inapa, Fonds Mercator, 1991), pp. 119-41.

${ }^{27}$ For the efforts of Portuguese diplomatic agents, like the envoy to Sweden in 1644, Rodrigo Botelho de Morais at these international summits, as part of the French and Swedish delegations; Pedro Cardim, "Portuguese Rebels” at Münster. 
the Spanish Monarchy, the Portuguese diplomats were denied official accreditation by the imperial authorities and had to make way their way to the summit as part of the French and Swedish delegations. To make matters worse, they were forced to look for shelter in the lodgings of their French and Swedish benefactors after attempts were made at their lives by pro-Spanish brigands. Physically threatened and unaccredited, the Braganza envoys had virtually no influence on settling the terms of the 1648 Agreements of Westphalia, which were unsurprisingly not well received in Portugal. The peace settlement was the last nail in the coffin for the anti-Habsburg entente envisioned by Joâo IV and his councillors, and, although Spain's conflict with France continued until 1659 Treaty of the Pyrenees, Madrid was now able to devote more attention to and mobilise more resources for the war with Portugal.

After 1648, the Portuguese Crown was under more pressure than ever to marshal funds, troops, rations and equipment for the war that would soon escalate with Spain. With that concern in mind, João de Guimarães Golias, Portugal's first resident diplomat in Sweden (serving from 1644 to 1649), ${ }^{28}$ reached out to the Swedish authorities and proposed that eight cargo-laden ships be dispatched to Lisbon every year for the coming years. ${ }^{29}$ These fleets should, in his estimation, be

The Diplomatic Self-Fashioning in Mid-17th Century European Politics', Historische Zeitschrift, 26 (1998), 294-333.

28 Among the diplomatic servants of the Portuguese Crown, residents were third-rank posts that ensured permanent representation at a foreign court. The appointees did not carry the same social capital as an ambassador, who tended to be someone from the highest-ranked court nobility, nor were they given the comparable decision-making power. Concomitantly, their remuneration was significantly lower than that of a de jure ambassador. Cardim, Monteiro, and Felismino, 'A Diplomacia Portuguesa', pp. 288-89.

29 João de Guimarães was the son of provincial urban elites (from the north-western town of Guimarães) and a university trained lawman. Prior to his diplomatic career, he served as a magistrate in Portugal's high-courts. After his commission in Sweden, his next appointment was in England. His tenure coincided with Cromwell's protectorate, during which Luso-English relations reached a low-point, due to King João IV's protection of royalists loyal to the House of Stuart. Rafael Marques de Lima, 'João de Guimarães Golias, o Homem e o Diplomata (1599-1653)', MA dissertation (Braga: Universidade do Minho-Instituto de Ciências Sociais, 2016). The correspondence of Guimarães about these matters is published in Fidelino de Figueiredo, 'Relaçôes 
escorted by two fifty-gun war-men, and the merchandise they carried would be paid for in salt, Indian pepper and Brazilian sugar.

To fit out these convoys and ensure that its cargoes were exchanged in Lisbon and other Portuguese ports, he suggested chartering a joint Luso-Swedish trade company, drawing capital and managerial expertise from both realms. Also, in exchange for a new diplomatic agreement to be ratified soon, Guimarães promised to convince Lisbon to allow, every year, two Swedish ships of the line into its East Indies ports for a triennium. According to the resident, Swedish merchants would be able to sell metal wares, arms and ammunitions in the ports of the Estado da India, where they could also acquire the prized Asian spices and textiles for their return voyage to Europe. Moreover, now that they were welcomed at the Portuguese outposts and could cooperate with the Estado da India's institutions and agents, Swedes had a better chance of consolidating their position in the Indian Ocean.

In Guimaráes' estimation, this deal could revive Portugal's dormant Cape Route shipping, allowing for provisions and reinforcements to be sent to Asia onboard Swedish Indiamen at a time when Lisbon could not spare money, ships, equipment and men because of its ongoing wars with Spain and the Dutch West India Company (WIC) in the South Atlantic.

Already by 1647 , there was a clear awareness that war with the Dutch Republic was brewing due to disputes over Northeastern Brazil, Ceylon and the Malabar coast. When the Portuguese resident in Sweden informed the ambassador in Paris, the Count of Vidigueira, that a voluminous cargo of metal wares and prime polish grain had just been dispatched from Gothenburg, he was instructed in reply to continue acquiring as much weaponry as possible for subsequent fleets. That same year, two of the Indiamen that the Portuguese sent to the East Indies had been purchased in Sweden.

The Swedish Crown tried, in turn, to capitalise on Portugal's more precarious position at the turn of the decade. It offered to expand the exports of arms, ammunition and naval wares in exchange for Swedish

Diplomáticas Entre Portugal e a Suécia (1644-1650). Subsídio Documental', Revista de História, 15, no. 57-60 (1926), 266-307. 
ships being granted access to the Lusitanian overseas ports, namely in Upper and Lower Guinea coasts. In response to these proposals, the Portuguese resident made it clear that his government would loosen the navigation and trade exclusives over its West African dwellings lightly.

Allowing foreign ships to drop anchor at its prized overseas ports was Portugal's ace in the hold in diplomatic negotiations with Europe's leading powers, and, unlike what Guimarães had indicated, Lisbon was not willing to play it for Sweden at that particular point in time. Still, despite the Portuguese Crown's reluctance, the second Swedish envoy, the Bremen-born Johan Frederick von Friesendorf, received instructions to persuade Lisbon to grant Swedish merchantmen access to the Portuguese West African ports right around the time that Sweden was trying to get its own African company off the ground. ${ }^{30}$ Moreover, he was also to convince the Portuguese authorities that it was in their best interest to favour the Swedes in the Setúbal salt business to balance out the predominance of Dutch importers. ${ }^{31}$

Among the proposals presented by Friesendorf to the Conselho da Fazenda (Council of the Exchequer) in Lisbon was a bi-annual convoy dispatched from Gothenburg to acquire salt at the Portuguese ports, with the remaining cargo space being filled with colonial goods and some metropolitan exports. By signing up for this project, the Portuguese consumers (including the Crown) could acquire the traditionally needed Nordic exports, while the royal exchequer could also raise money by levying tariffs on some of the goods carried on these convoys. ${ }^{32}$

However, Friesendorf was convinced that the best way to further Swedish interests with regard to the Portuguese empire was by reaching

${ }^{30}$ For an overview of the plans for and vicissitudes of the take-off of the Swedish Atlantic expansion with special reference to the Western Coast of Africa, see Kaarle Wirta, Early Modern Overseas Trade and Entrepreneurship: Nordic Trading Companies in the Seventeenth Century (New York: Routledge, 2020).

31 Salt (or taxation rights over salt) was used as a hard-currency in both the trade between Portuguese ports and the Amsterdam staple market and in the payment of war compensations over the loss of Dutch Brazil by the Braganza kings to the States General. For that reason, ships freighted by Dutch merchants were given priority over their English, German and Scandinavian counterparts when it came to load salt in Setubal and other salt ports.

32 Mellander and Prestage, The Diplomatic and Commercial Relations, pp. 71-72. 
out to the Companhia Geral do Comércio do Brasil that was formed in 1649. This regulated company oversaw the trade in some staple products, the protection of merchantmen at high-sea and the mobilisation of military resources to Portuguese America. ${ }^{33}$ Alongside accessing the Indian Ocean and West-African ports, the prospect of trading with Brazil resonated with Swedish commercial interests. Already in 1647, João de Guimarães had waved with ten annual permits to trade with Portuguese West Indies ports to convince Oxenstierna's cabinet to sign a new treaty, but the offer was immediately shut-down by the Paris ambassador and by Lisbon. Still, the fact that the possibility was suggested by the Crown's official representative in Stockholm shows that the Swedish business circles were receptive to proposals involving the South Atlantic trade.

This was not the first time that this idea had been floated. In previous talks held with members of the Swedish cabinet, which included the Lord High Chancellor Oxenstierna himself, Portuguese envoys had been told of the Swedish interest in securing similar concessions to those granted to the Dutch in 1641 and the English in $1642 .{ }^{34}$ But if this interest was to be materialised, the late 1650 s were the appropriate moment.

The commercial clauses of these treaties enabled Portuguese investors and merchants to freight Dutch and English ships for the purpose of trading with Brazil, while merchants from these countries could also chart voyages to and call at a few designated ports on the Western African coast. Moreover, in the eight years separating the 1640 coup d'état from the charting of the Companhia Geral, the Portuguese had relied on Dutch and English vessels to trade with their territories in Brazil (except for the north-eastern areas, which were at the time under the aegis of the WIC). However, the outbreak of a revolt in Dutch

33 Every year, the company had to assemble an armed convoy to escort the merchant fleet that sailed from Lisbon to Brazil. In return for bearing with the protection costs of the transatlantic trade, the Crown granted the company a monopoly on the staple goods of the Portuguese export trade with Brazil: wheat flour, olive oil, wine and dried cod. Leonor Freire Costa, O transporte no Atlântico e a Companhia Geral do Comércio do Brasil, 1580-1663 (Lisbon: Comissão Nacional para as Comemoraçóes dos Descobrimentos Portugueses, 2002).

34 Mellander and Prestage, The Diplomatic and Commercial Relations, pp. 28-29. 
Brazil in 1645, allegedly encouraged by the Portuguese monarch (or at least by figures close to him), followed by the recapture of Angola in 1648, re-ignited the flames of war between Portugal and the Dutch Republic. ${ }^{35}$ The directors of the newly charted company then turned to English skippers to assemble the biannual armed convoy, comprising eighteen war-men and a large number of merchant vessels, that would ensure a safe and steady connection between Lisbon and Brazil. ${ }^{36}$ The logistics of the Companhia Geral do Comércio do Brasil, therefore, allowed English interests to encroach on the trade with the Portuguese colony in America, garnering them a new customer to its shipping services sector and a potential new world market where they could place its manufactures and the dried cod from its Newfoundland and New England fisheries. ${ }^{37}$

However, the English were not the only foreign interest that saw the Companhia Geral as a means to make headway in the export to markets of Portugal's most prized Atlantic possession, Brazil. Friesendorf was quick to realise the opportunity represented by the company and engaged in talks with the board of directors. Although most of the documentation on the company's management has been lost, the records from Sweden's diplomatic agencies shed some light on the inquiries made.

35 Mello, O Negócio Do Brasil; Evaldo Cabral de Mello, Olinda restaurada: guerra e açúcar no Nordeste, 1630-1654 (Rio de Janeiro: Topbooks, 1998).

${ }^{36}$ On the penetration of English interests in the Brazil trade via their input in the freighting and outfitting of the Brazil company fleets, see Leonor Freire Costa, 'Da Restauração a Methuen: Ruptura e Continuidade', in O Tratado de Methuen (1703). Diplomacia, Guerra, Politica e Economia, ed. by José Luís Cardoso et al. (Lisbon: Livros Horizonte, 2003), pp. 35-39; Charles R. Boxer, 'English Shipping and the Brazil Trade. 1640-1665', Marriner's Mirror, 37, no. 3 (1951), 197-230; Charles R. Boxer, 'As primeiras frotas da Companhia do Brasil à luz de três documentos inéditos. 1648-1652', Anais Do Congresso de História Nacional, V, no. 5 (1949), 299-359.

37 On the supply of dried cod as a vehicle of English encroachment on the trade with Brazil; Costa, 'Da Restauração a Methuen', pp. 37-39. For an overall assessment on the English/North American supplying chains of dried cod to the Iberian world, see Darlene Abreu-Ferreira, 'Terra Nova through the Iberian Looking Glass: The Portuguese-Newfoundland Cod Fishery in the Sixteenth Century', Canadian Historical Review, 79, no. 1 (1998), 100-17; Regina Grafe, Distant Tyranny: Markets, Power, and Backwardness in Spain, 1650-1800 (Princeton: Princeton University Press, 2012), chapter 3. 
Approached by Friesendorf, the board of directors clarified the terms under which Swedish merchants and skippers could engage with the company. There were three ways to do so: shareholding, integrating Swedish ships charted by the Crown and non-institutional investors in convoy, and freighting Swedish vessels by the company itself. First, Swedish investors could acquire shares in the venture by pledging ships and naval stores to the company. Any ships authorised to sail with the convoy would do so under the command of the admiral appointed by the company, and while a sea, they should under no pretext split from the escort fleet. Upon dropping anchor in Lisbon, at the end of the return trip, and before departing for Sweden, these ships would pay the standard tariffs at the customhouses of the Portuguese capital. Swedish ships were also banned from carrying wine, olive oil, dried codfish and wheat flour to Brazil unless they had been freighted by the company for that purpose, since, according to the charter, only the Companhia Geral was allowed to export these four staple goods. The general guidelines for future freight contracts between the company and Swedish skippers were also outlined for chartered Swedish ships. Their ships could stay in Lisbon for up to two months following their arrival from Scandinavia or the Baltic, three weeks in Madeira if they called at the archipelago on their way to Brazil, and up to four months at their destination. ${ }^{38}$

It is not exactly clear why, but it appears that the negotiations broke down. The Swedish resident blamed the lack of commitment by the Stockholm authorities for the failure to reach what could have been a profitable agreement with the Companhia and the Portuguese Crown. Although the timeline is not entirely clear, one of the factors that could have disrupted the negotiations was the establishment of the Swedish dwelling of Cape Coast Castle in 1650, which immediately soured the relationships between the two states. Lisbon saw the inception of a Swedish foothold on the Gold Coast as another threat to its interests in the region, which had already been seriously disrupted by the Dutch conquest of El-Mina in 1630. ${ }^{39}$

38 Lima, 'As Relaçóes de Portugal', pp. 403-04.

39 Filipa Ribeiro da Silva, Dutch and Portuguese in Western Africa: Empires, Merchants and the Atlantic System, 1580-1674 (Leiden-Boston: Brill, 2011). 
The importance of commercial and overseas affairs in the political communication between the two Crowns can again be surmised from the appointment of José Pinto Pereira to the post of resident at Stockholm in 1650. Although his primary assignment was to keep an eye on the trade of Scandinavian and Baltic wares to the shipyards and military stores of the Dutch Republic, he also received instructions to resume talks regarding the situation on the Guinea Coast. Pinto Pereira was an obvious choice to oversee negotiations on colonial matters, being one of the country's leading authorities in overseas affairs. In the past, he had served as treasurer of the Casa da India, Portugal's central agency for the overseas trade logistics and tax collection, and before that as a financial overseer in Goa. ${ }^{40}$ During his commission in Stockholm, he tried to revive the old project of a joint Portuguese-Swedish Africa company, along with the strategic partnership East of the Cape of Good Hope, but to no avail.

By this point, it is safe to say that the interest of the Swedish Crown and courtly figures in Portugal and its empire had cooled off. Although this diminished interest had partially to do with the realisation by the authorities in Stockholm that Lisbon was unwilling to open its Western African footholds to Swedish trade, the main reason was the improvement of the diplomatic relations with Spain in the wake of the Peace of Westphalia and the new-found interest of Sweden's maritime sector in Spanish salt.

In 1651, the Portuguese resident estimated that Sweden imported 11,300 barrels of salt from Spain and only 8,600 from Portugal every year. The retrieval of Dutch Brazil by the Portuguese Crown after 1654 , and the pacification of the transatlantic shipping in the years that followed, also meant that the window of opportunity for colonial cooperation between Portugal and Sweden was closed. Conversely, a treaty was ratified with England in the same year, that saw Cromwell's Protectorate extract significant economic concessions from a financial and militarily weakened Portuguese Crown. Chief among them was

${ }^{40}$ He was reportedly one of Lars Skytte's closest acquaintances prior to the latter's sudden and unexpected conversion to Catholicism Lima, 'As Relaçóes de Portugal', p. 362. 
the privileges given to English skippers in the transatlantic trade with Brazil that Friesendorf had tried to secure for Sweden. ${ }^{41}$

By the turn of the 1670s, the diplomatic records became filled with mundane accounts of payment arrears involving Swedish merchants and skippers in Lisbon or complications in the procurement of salt in Setúbal and other ports. The sense of urgency and the daring commercial plans that transpired in the correspondence of the external representatives of both monarchies during the 1640s and 1650s had all but disappeared. ${ }^{42}$

The trade between Portugal and Scandinavian and Baltic territories of the House of Wittelsbach would eventually pick up some steam in the last quarter of the century when Spain had already recognised Portugal as an independent kingdom, and a general peace between the two monarchies agreed. ${ }^{43}$ In the decades that immediately preceded

41 In 1650, an English war fleet castigated the Portuguese Crown for having granted asylum to two royalist princes, Maurice and Rupert. The Republican armada blocked the estuary of the river Tagus and unloaded its cannons at the returning fleet of the Companhia Geral, seizing or sinking numerous ships and valuable sugar cargoes they carried. In the wake of this diplomatic and commercial debacle, Cromwell was in the position to force its hand on João IV and signed a treaty that was a highly advantageous to England.

42 Between 1662 and 1669, Albrecht Otto von Vegesack, member of a lineage with strong links to the Baltic trade, was appointed the monarchy's consul in Portugal, the first of its kind in the history of Sweden's foreign affairs.

43 According to Virginia Rau, from 1680 to 1690, nearly 1500 foreign ships dropped anchor in Setubal. Out of these 1076 hoisted a Dutch flag, which perfectly illustrate the dominance of Netherlandish merchants in the Portuguese salt imports to Northern Europe and the Baltic. Coming at a distant second were English vessels, which amounted to 169 voyages. For their part, Swedish vessels only came in fifth place, with 38 ships, behind merchantmen from German cities with 70 and Danish/ Norwegian with 68! Virgínia Rau, 'Rumos e Vicissitudes Do Comércio Do Sal Português Nos Séculos XIV a XVIII', Revista Da Faculdade de Letras de Lisboa, 3, no. 7 (1963). In turn, Swedish consular reports and quantitative data drawn from the Sound toll records indicates that at the turn of the eighteenth century the number of Swedish ships visiting Portuguese ports every year doubled, from roughly 20 in the 1680 s to more than 40 in 1700 . These figures provide, in all likelihood, a more accurate picture of the direct traffic between Sweden and Portugal than Rau's estimates. Jari Ojala et al., 'Trade between Sweden and Portugal in the Eighteenth Century: Assessing the Reliability of STRO Compared to Swedish and Portuguese Sources', in Early Modern Shipping and Trade. Novel Approaches Using Sound Toll Registers Online, 
and followed 1701, regular merchant shipping with Iberian ports was encouraged by the Swedish government to reduce the reliance on Dutch shipping. Charles Gustav's Navigation Acts, which formally closed Sweden's ports to foreign merchant marines, along with the second and third Anglo-Dutch War, invited Swedish skippers to venture into the Iberian Peninsula. Even with the armed conflicts that pitted Sweden against Poland and Denmark (the Great Northern War of 1710-21) destabilising navigation in the Danish Sound and the Baltic, the reliance on foreign shipping in the Swedish-Portuguese trade was never as pronounced as it was in the mid-seventeenth century.

By the 1720s, Swedish skippers had overtaken the Dutch merchant marine as the prime movers of salt, iron and steel between Portugal and Sweden, in no small part thanks to the Swedish Navigation Acts of 1724. Going into the eighteenth century, Portugal became undoubtedly Sweden's leading commercial partner in Southern Europe, and the consulate founded in Lisbon in 1660 was one of the most important in the Swedish consular system. ${ }^{44}$

\section{CONCLUSIONS}

Inspired by the novel actor-based approach of New Diplomatic History, this article offers an outsider's perspective on Sweden's commercial and colonial ambitions during the second half of the seventeenth century. At the same time, it examines how the Portuguese Crown, and the kingdom's political and economic elites looked to the Swedish monarchy as it prepared for its wars in the Iberian Peninsula and overseas. For its part, the Scandinavian monarchy was not directly affected by the Braganza's foreign policy moves and the events unfolding in Portugal's overseas extensions and became even less interested in them as years and decades went on. This becomes clear when one looks at the profile of the first Swedish residents in Portugal. Both Skytte and Friesendorf had a merchant background and lacked the social capital and political influence to change their monarchy's diplomatic agenda

ed. by Jan Willem Veluwenkamp and Werner Scheltjens (Boston-Leiden: Brill, 2018), pp. 153-54; Müller, Consuls, Corsairs, and Commerce, p. 51.

${ }^{44}$ Müller, 'Swedish Trade and Swedish Consular Services', p. 97. 
with regard to Portugal. On the other hand, they had a good eye for economic opportunities and a good understanding of Portugal's commercial situation, which came in handy when dealing with Portugal's merchant class and officials in the financial, military, and overseas administration.

Their Portuguese counterparts in Sweden could be characterised along similar lines. Except for the ambassador Sousa Coutinho, who was sent to formally open diplomatic negotiations and sign an initial inter-state agreement, they were royal officials with a background in law and particular expertise in economic and colonial matters, not figures of the court-aristocracy. The official delegates of both polities correspond to the profile of diplomatic actors that would have been considered eccentric (or would have been simply neglected) by the traditional diplomatic historiography, but which new diplomatic history has thrust into the limelight.

Although the Swedish Crown did not derive direct political benefits from its relation with Portugal, its diplomatic envoys nonetheless watched over the political and economic fragilities of the Lusitanian kingdom in the hope of securing economic advantages. Portuguese salt played a pivotal role in the Nordic and Baltic maritime sector, and the nascent Swedish overseas empire could make strides by partnering with an established but strained colonial power such as Portugal. Plus, a fair amount of military and naval equipment was exported in the years following Sousa Coutinho's 1641 mission, which benefited both the Swedish metallurgical industry and Portugal's hard-pressed armies and naval forces.

This overview of the early relations between a distinguished military and metallurgical power and a kingdom looking for international recognition and the means to fight wars in far-flung corners of the world serves as a case study for the entanglement of trade and international relations. This article contends that seventeenth-century Sweden became increasingly aware of business interests and opportunities outside the Baltic and Scandinavia, which attests to its growing imperial vocation. The article equally posits that the material resources from the Nordic regions and Northeastern Europe remained instrumental to the Iberian economies and their state and empire-making projects. 
While being very different political-territorial formations, both the Swedish and the Portuguese empires relied on multilateral connections with foreign states and markets to be economically feasible and resilient to enemy assault and conquest. Such trans-regional and trans-imperial links were brokered, sustained and subsequently expanded in considerable measure by diplomatic cadres recruited from different backgrounds, ranging from the aristocracy to university-educated officials and merchants. They all put their particular expertise, social capital, and contacts to bear on the conduction of their respective Crown's foreign affairs agenda. In the process, they put their stamp on official directives and adapted them to accommodate their own goals.

\section{BIBLIOGRAPHY}

\section{Printed primary sources}

Relação das armas que do Reyno de Suecia tras Francisco de Sousa Coutinho, embaixador as partes Septentrionais, em três naos de guerra (1642), in Moses Bensabat Amzalak, A embaixada enviada pelo Rei D. João IV à Dinamarca è Suécia: notas e documentos (Lisboa: Gráfica do Instituto Superior do Comércio de Lisboa, 1930), p. 31

\section{Secondary Works}

Abreu-Ferreira, Darlene, 'Terra Nova through the Iberian Looking Glass: The Portuguese-Newfoundland Cod Fishery in the Sixteenth Century', Canadian Historical Review, 79, no. 1 (1998)

Amzalak, Moses Bensabat, A embaixada enviada pelo Rei D. Joáo IV à Dinamarca e à Suécia: notas e documentos (Lisboa: Gráfica do Instituto Superior do Comércio de Lisboa, 1930)

Antunes, Cátia, 'Dutch-Portuguese Diplomatic Encounters, 1640-1703: Exchanges, Sovereignty and "World Peace", Journal of Early Modern History, 23, no. 5 (2019) , 'Failing Institutions: The Dutch in Portugal and the Tale of a Sixteenth-Century Firm', Storia Economica, 18, no. 2: Reti Finanziarie e Reti Commerciali. Operatori Economici Stranieri in Portogallo (XVI-XVII Secolo), ed. by Benedetta Crivelli and Gaetano Sabatini (2015)

Boxer, Charles R., 'As Primeiras Frotas Da Companhia Do Brasil à Luz de Três Documentos Inéditos. 1648-1652', Anais Do Congresso de História Nacional, V, no. 5 (1950)

37, no. 3 (1951) 
Cardim, Pedro, "Portuguese Rebels" at Münster. The Diplomatic Self-Fashioning in Mid-17th Century European Politics', Historische Zeitschrift, 26 (1998)

Nuno Gonçalo Monteiro, and David Felismino, 'A Diplomacia Portuguesa No Antigo Regime. Perfil Sociologico e Trajectórias', in Optima Pars. Elites IberoAmericanas Do Antigo Regime, ed. by Nuno Gonçalo Monteiro, Pedro Cardim, and Mafalda Soares da Cunha (Lisbon: Imprensa de Ciências Sociais, 2005)

Castro, José Ferreira Borges de, Colleccao dos Tratados, Convencoes, Contratos e Actos Publicos Celebrados Entre a Coroa de Portugal e as Mais Potencias, vol. 1 (Lisbon: Imprensa Nacional, 1856)

Childs, John, 'The English Brigade in Portugal, 1662-68', Journal of the Society for Army Historical Research, 53, no. 215 (1975)

Costa, Leonor Freire, 'Da Restauração a Methuen: Ruptura e Continuidade', in O Tratado de Methuen (1703). Diplomacia, Guerra, Politica e Economia, ed. by José Luís Cardoso, Isabel Cluny, Fernando Dores Costa, Leonor Freire Costa, Conceição Andrade Martins, Nuno Gonçalo Monteiro, and Jorge Pedreira (Lisbon: Livros Horizonte, 2003)

O transporte no Atlântico e a Companhia Geral do Comércio do Brasil, 1580-1663 (Lisbon: Comissão Nacional para as Comemoraçôes dos Descobrimentos Portugueses, 2002)

and Mafalda Soares da Cunha, D. João IV (Rio de Mouro: Círculo de Leitores, 2006)

, 'Relaçôes Diplomáticas Entre Portugal e a Suécia (1644-1650). Subsídio Documental', Revista de História, 15, no. 57-60 (1926)

Freitas, Jorge Penim de, $O$ combatente durante a guerra da restauração: vivência e comportamento dos militares ao serviço da coroa portuguesa 1640-1668 (Lisbon: Prefacio, 2007)

Grafe, Regina, Distant Tyranny: Markets, Power, and Backwardness in Spain, 1650-1800 (Princeton: Princeton University Press, 2012)

Herrero Sánchez, Manuel, El Acercamiento Hispano-Neerlandés (1648-1678) (Madrid: Consejo Superior de Investigaciones Científicas, 2000)

Israel, Jonathan I, 'The Politics of International Trade Rivalry during the Thirty Years' War: Gabriel de Roy and Olivares' Mercantilistic Projects, 1621-1645', in Empires and Entrepots: Dutch, the Spanish Monarchy and the Jews, 1585-1713 (LondonRonceverte: The Hambledon Press, 1990)

Lilja, Sven, 'Peoples, Towns and States. Structural Power Resources and State Power in the Scando-Baltic Region (1500-1820)', in The Dynamics of Economic Culture in the North Sea and Baltic Region in Late Middle Ages and Early Modern Period, ed. by Hanno Brand and Leos Müller (Hilversum: Verloren, 2007)

Lima, Durval Pires de, 'As Relações de Portugal Com a Suécia Durante a Restauração', Separata de Anais Da Academia Portuguesa de História, 7 (Publicaçóes comemorativas do duplo centenário da Fundação e Restauração de Portugal) (1942)

Lima, Rafael Marques de, 'João de Guimarães Golias, o Homem e o Diplomata (1599-1653)', MA dissertation (Braga: Universidade do Minho-Instituto de Ciências Sociais, 2016) 
Lorraine White, 'Strategic Geography and the Spanish Habsburg Monarchy's Failure to Recover Portugal, 1640-1668', Journal of Military History, 71, no. 2 (2007)

Macedo, Jorge Borges de, História diplomática portuguesa: constantes e linhas de força, vols 1-2, 2nd edn (Lisbon: Tribuna da História, 2006)

Mellander, Karl, and Edgar Prestage, The Diplomatic and Commercial Relations of Sweden and Portugal from 1641 to 1670 (Watford: Voss and Michael, 1930)

Mello, Evaldo Cabral de, O Negócio Do Brasil. Portugal, Os Países Baixos e o Nordeste (1641-1669) (Lisbon: Comissão Nacional para as Comemorações dos Descobrimentos Portugueses, 2001)

Olinda restaurada: guerra e açúcar no Nordeste, 1630-1654 (Rio de Janeiro: Topbooks, 1998)

Mörner, Magnus, 'Swedish Trade and Shipping with the Iberian Peninsula. From the 16th Century to the 19th Century', in III Spain and Sweden: Encounters Throughout History, ed. by Enrique Martínez Ruiz and Magdalena Pi Corrales (Puertollano: Berndt Wistedt, 2000)

Müller, Leos, Consuls, Corsairs, and Commerce: The Swedish Consular Service and Long-Distance Shipping, 1720-1815 (Uppsala: Coronet Books Incorporated, 2004)

, 'Swedish Trade and Swedish Consular Services, 1700-1800', in A Articulação Do Sal Português Aos Circuitos Mundiais. Antigos e Novos Consumos / The Articulation of Portuguese Salt with Worldwide Routes. Past and New Consuption Trends, ed. by Inês Amorin (Oporto: IHM-UP, 2008)

Ojala, Jari, Lauri Karvonen, Maria Cristina Moreira, and Jari Eloranta, 'Trade between Sweden and Portugal in the Eighteenth Century: Assessing the Reliability of STRO Compared to Swedish and Portuguese Sources', in Early Modern Shipping and Trade. Novel Approaches Using Sound Toll Registers Online, ed. by Jan Willem Veluwenkamp and Werner Scheltjens (Boston-Leiden: Brill, 2018)

Pereira, Edgar, and Kaarle Wirta, 'A Forgotten Emporium: Commercial Aspirations and Transnational Mercantile Networks in Seventeenth-Century Glückstadt', in Locating the Global. Spaces, Networks and Interactions from the Seventeenth to the Twentieth Century, ed. by Holger Weiss (Berlin-Boston: De Gruyter, 2020)

Poettering, Jorun, Migrating Merchants: Trade, Nation, and Religion in SeventeenthCentury Hamburg and Portugal (Berlin-Boston: de Gruyter, 2018)

Rau, Virgínia, 'Rumos e Vicissitudes Do Comércio Do Sal Português Nos Séculos XIV a XVIII', Revista Da Faculdade de Letras de Lisboa, 3, no. 7 (1963)

, 'Subsídios Para o Estudo Do Movimento Dos Portos de Faro e Lisboa Durante o Século XVII', Separata de Anais Da Academia Portuguesa de História, $2^{\mathrm{a}}$, no. 5 (1954)

Ribeiro, Ana Sofia, Amélia Polónia, Cátia Antunes, and Miguel Nogueira, 'Portugal and the Baltic Trade. An Overview, 1634-1800', in Seaports in the First Global Age. Portuguese Agents, Networks and Interactions (1500-1800), ed. by Amélia Polónia and Cátia Antunes (Oporto: U. Porto Ediçóes, 2016)

Rodrigues, Miguel Geraldes, 'Between West Africa and America. The Angolan Slave Trade in the Portuguese and Spanish Atlantic Empires (1560-1641)', PhD dissertation (Firenze: European University Institute, Department of History and Civilization, 2019) 
Silva, Filipa Ribeiro da, Dutch and Portuguese in Western Africa: Empires, Merchants and the Atlantic System, 1580-1674 (Leiden-Boston: Brill, 2011)

Sowerby, Tracey A., 'Early Modern Diplomatic History', History Compass, 14, no. 9 (2016)

and Jan Hennings, 'Introduction', in Practices of Diplomacy in the Early Modern World c. 1410-1800, ed. by Tracey A. Sowerby and Jan Hennings (New York: Routledge, 2017)

Stols, Eddy, 'A “nação" Flamenga Em Lisboa', in Flandres e Portugal. Na Confluência de Duas Culturas, ed. by John Everaert and Eddy Stols (Antwerp: Ediçóes Inapa, Fonds Mercator, 1991)

Tremml-Werner, Birgit, and Dorothée Goetze, 'A Multitude of Actors in Early Modern Diplomacy', Journal of Early Modern History, 23, no. 5 (2019)

Valladares, Rafael, 'La Dimensión Marítima de La Empresa de Portugal (1640-1668)', in "Por Toda La Tierra". España y Portugal: Globalización y Ruptura (1580-1700) (Lisbon: Cham, 2016) , La rebelión de Portugal: guerra, conflicto y poderes en la monarquía hispánica, 1640-1680 (Valladolid: Junta de Castilla y León-Consejería de Educación y Cultura, 1998)

Watkins, John, 'Toward a New Diplomatic History of Medieval and Early Modern Europe', Journal of Medieval and Early Modern Studies, 38, no. 1 (1 Jan. 2008)

Wirta, Kaarle, Early Modern Overseas Trade and Entrepreneurship: Nordic Trading Companies in the Seventeenth Century (New York: Routledge, 2020)

Edgar Pereira $(\mathrm{PhD})$ - received his $\mathrm{PhD}$ at Leiden University in 2020, currently a postdoctoral researcher at the Faculty of Humanities of the University of Coimbra. His main interests lie in intersection between the history of Iberian imperial projection and the entanglement of business enterprise and state formation; e-mail: epereira@fl.uc.pt 